\title{
Reduction of the Ring Size of Radiolabeled Lactam Bridge-Cyclized $\alpha$-MSH Peptide, Resulting in Enhanced Melanoma Uptake
}

\author{
Haixun Guo ${ }^{1}$, Jianquan Yang ${ }^{1}$, Fabio Gallazzi² ${ }^{2}$, and Yubin Miao ${ }^{1,3,4}$ \\ ${ }^{1}$ College of Pharmacy, University of New Mexico, Albuquerque, New Mexico; ${ }^{2}$ Department of Biochemistry, University of Missouri, \\ Columbia, Missouri; ${ }^{3}$ Cancer Research and Treatment Center, University of New Mexico, Albuquerque, New Mexico; and \\ ${ }^{4}$ Department of Dermatology, University of New Mexico, Albuquerque, New Mexico
}

\begin{abstract}
The purpose of this study was to examine the profound effect of the ring size of the radiolabeled lactam bridge-cyclized $\alpha$-melanocyte-stimulating hormone $(\alpha-\mathrm{MSH})$ peptide on its melanoma-targeting properties. Methods: A novel cyclic $\alpha-\mathrm{MSH}$ peptide, 1,4,7,10-tetraazacyclododecane-1,4,7,10-tetraacetic acid-Nle-c[Asp-His-D-Phe-Arg-Trp-Lys]-CONH ${ }_{2}$ (DOTA-Nle$\mathrm{CycMSH}_{\text {hex }}$ ), was synthesized and radiolabeled with ${ }^{111} \mathrm{In}$. The melanocortin-1 receptor-binding affinity of DOTA-Nle-CycMSH $\mathrm{H}_{\text {hex }}$ was determined in B16/F1 melanoma cells. The internalization and efflux of ${ }^{111} \mathrm{In}$-DOTA-Nle-CycMSH $\mathrm{Hex}_{\text {her }}$ were examined in B16/F1 cells. The melanoma-targeting properties and SPECT/ CT characteristics of ${ }^{111}$ In-DOTA-Nle-CycMSH $\mathrm{H}_{\text {hex }}$ were determined in B16/F1 melanoma-bearing C57 mice. Results: DOTA-Nle-CycMSH hex displayed $1.77 \mathrm{nM}$ receptor-binding affinity. ${ }^{111} \mathrm{In}$-DOTA-Nle-CycMSH $\mathrm{H}_{\text {hex }}$ exhibited rapid internalization and extended retention in B16/F1 cells. The tumor uptake of ${ }^{111} \mathrm{In}-\mathrm{DOTA}-\mathrm{Nle}-\mathrm{CycMSH}_{\text {hex }}$ was $24.94 \% \pm 4.58 \%$ and $10.53 \% \pm 1.11 \%$ injected dose per gram at 0.5 and $24 \mathrm{~h}$ after injection, respectively. Greater than $82 \%$ of the injected radioactivity was cleared through the urinary system by $2 \mathrm{~h}$ after injection. The tumor-to-kidney uptake ratios reached 2.04 and 1.70 at 2 and $4 \mathrm{~h}$ after injection, respectively. Flank melanoma tumors were clearly visualized by SPECT/CT using ${ }^{111} \mathrm{In}$-DOTA-Nle$\mathrm{CyCMSH}_{\text {hex }}$ as an imaging probe at 2 and $24 \mathrm{~h}$ after injection. The radioactivity accumulation in normal organs, except for the kidneys, was low at 2, 4, and $24 \mathrm{~h}$ after injection. Conclusion: The reduction of the peptide ring size dramatically increased the melanoma uptake and decreased the renal uptake of ${ }^{111} \mathrm{In}$ DOTA-Nle-CycMSH $\mathrm{H}_{\text {hex }}$, providing a new insight into the design of a novel radiolabeled lactam bridge-cyclized $\alpha-\mathrm{MSH}$ peptide for melanoma imaging and treatment.
\end{abstract}

Key Words: melanoma imaging; radiolabeled cyclic peptide; $\alpha$-melanocyte-stimulating hormone; small-animal imaging

J Nucl Med 2010; 51:418-426

DOI: 10.2967/jnumed.109.071787

Received Oct. 20, 2009; revision accepted Dec. 3, 2009.

For correspondence or reprints contact: Yubin Miao, 2502 Marble NE, MSC09 5360, College of Pharmacy, University of New Mexico, Albuquerque, NM 87131.

E-mail: ymiao@salud.unm.edu

COPYRIGHT @ 2010 by the Society of Nuclear Medicine, Inc.
$\mathbf{S}_{k}$ cancer is the most commonly diagnosed cancer in the United States. Melanoma accounts for less than $5 \%$ of skin cancer cases but causes greater than $75 \%$ of deaths from skin cancer. It is predicted that 68,720 new cases will be diagnosed and 8,650 deaths will occur in 2009 (1). Early diagnosis and prompt surgical removal are the best opportunities for a patient's cure, because no curative treatment exists for metastatic melanoma. Despite the clinical use of ${ }^{18}$ F-FDG for PET diagnosis and staging of melanoma, ${ }^{18} \mathrm{~F}-\mathrm{FDG}$ is not a melanoma-specific imaging agent and is also not effective in imaging small melanoma metastases $(<5 \mathrm{~mm})$ and melanomas that have primary energy sources other than glucose (2-4). Alternatively, melanocortin-1 (MC1) receptor is a distinct molecular target because of its overexpression on both human and mouse melanoma cells (5-9). Radiolabeled $\alpha$-melanocytestimulating hormone $(\alpha-\mathrm{MSH})$ peptides can bind the MC1 receptors with nanomolar binding affinities (10-20) and represent a class of promising melanoma-specific radiopharmaceuticals for melanoma imaging and therapy.

Recently, we have developed a novel class of ${ }^{111} \mathrm{In}$ labeled lactam bridge-cyclized 1,4,7,10-tetraazacyclododecane-1,4,7,10-tetraacetic acid (DOTA)-conjugated $\alpha$-MSH peptides for melanoma detection $(21,22)$. Lactam bridge cyclization was used to improve the stabilities of the $\alpha-\mathrm{MSH}$ peptides against the proteolytic degradations in vivo and enhance the binding affinities of the $\alpha$-MSH peptides through stabilization of their secondary structures such as $\beta$-turns (23-26). The radiometal chelator DOTA was attached to the $\mathrm{N}$ terminus of the lactam bridge-cyclized $\alpha$-MSH peptide (12 amino acids in the peptide ring) for ${ }^{111}$ In radiolabeling. For instance, ${ }^{111}$ In-DOTA-GlyGluCycMSH ( ${ }^{111}$ In-DOTA-Gly-Glu-c[Lys-Nle-Glu-His-D-PheArg-Trp-Gly-Arg-Pro-Val-Asp]) exhibited high MC1 receptor-mediated tumor uptake $(10.40 \pm 1.40$ percentage injected dose per gram [\% ID/g] at $2 \mathrm{~h}$ after injection) in flank B16/F1 melanoma-bearing C57 mice (21). Both primary and pulmonary metastatic melanoma flank lesions were clearly visualized by small-animal SPECT/CT using 
${ }^{111}$ In-DOTA-GlyGlu-CycMSH as an imaging probe $(21,22)$, highlighting its potential as an effective imaging probe for melanoma detection.

One advantage of the lactam bridge-cyclized $\alpha-\mathrm{MSH}$ peptide is that the peptide ring size can be finely modified by either adding or deleting amino acids without sacrificing the binding affinity of the peptide $(21,22)$. The studies on the $\alpha$-MSH peptide agonists for the MC1 receptor revealed that the lactam bridge-cyclized $\alpha$-MSH peptide with a 6-amino acid peptide ring (Ac-Nle-c[Asp-His-D-Phe-ArgTrp-Lys $\left.\left(\mathrm{CONH}_{2}\right)\right]$ ) displayed not only higher $\mathrm{MC1}$ receptor-binding affinity but also a slower $\mathrm{MC} 1$ receptor dissociation rate than the native $\alpha$-MSH peptide (Ac-SerTyr-Ser-Met-Glu-His-Phe-Arg-Trp-Gly-Lys-Pro-Val-NH ${ }_{2}$ ) $(27,28)$. A slow MC1 receptor dissociation rate might contribute to the prolonged biologic activity of Ac-Nlec[Asp-His-D-Phe-Arg-Trp-Lys $\left(\mathrm{CONH}_{2}\right)$ in vitro and in vivo (27). In this study, we conjugated the radiometal chelator DOTA to the $\mathrm{N}$ terminus of the Ac-Nle-c[Asp-His-D-PheArg-Trp-Lys $\left(\mathrm{CONH}_{2}\right)$ peptide to generate a novel DOTAconjugated lactam bridge-cyclized $\alpha$-MSH peptide with a 6-amino acid peptide ring (DOTA-Nle-CycMSH $\mathrm{MSx}_{\text {hex }}$ ) to examine the effect of peptide ring size on its melanomatargeting and pharmacokinetic properties. The MC1 receptorbinding affinity of DOTA-Nle-CycMSH $\mathrm{MS}_{\text {hex }}$ was determined in B16/F1 melanoma cells. DOTA-Nle-CycMSH $\mathrm{CHx}_{\text {hex }}$ was radiolabeled with ${ }^{111} \mathrm{In}$, a commercially available diagnostic radionuclide with a half-life of $2.8 \mathrm{~d}$. The melanomatargeting and pharmacokinetic properties and SPECT/CT of ${ }^{111}$ In-labeled DOTA-Nle-CycMSH ${ }_{\text {hex }}$ were determined in B16/F1 melanoma-bearing C57 mice.

\section{MATERIALS AND METHODS}

\section{Chemicals and Reagents}

Amino acid and resin were purchased from Advanced ChemTech Inc. and Novabiochem. DOTA-tri-t-butyl ester was purchased from Macrocyclics Inc. ${ }^{111} \mathrm{InCl}_{3}$ was purchased from Trace Life Sciences, Inc. $\left.{ }^{125} \mathrm{I}_{-\mathrm{Tyr}^{2}-\left[\mathrm{Nle}^{4}, \mathrm{D}-\mathrm{Phe}\right.}{ }^{7}\right]-\alpha-\mathrm{MSH}\left({ }^{125} \mathrm{I}_{-}-\left(\mathrm{Tyr}^{2}\right)-\right.$ NDP-MSH) was obtained from PerkinElmer, Inc. All other chemicals used in this study were purchased from Thermo Fischer Scientific and used without further purification. B16/F1 melanoma cells were obtained from American Type Culture Collection.

\section{Peptide Synthesis}

DOTA-Nle-CycMSH $\mathrm{Mex}_{\text {hex }}$ was synthesized using standard fluorenylmethyloxycarbonyl chemistry. Briefly, an intermediate scaffold of ( $\mathrm{tBu})_{3}$ DOTA-Nle-Asp(O-2-PhiPr)-His(Trt)-D-Phe-Arg(Pbf)$\operatorname{Trp}$ (Boc)-Lys(Dde) was synthesized on $\mathrm{H}_{2} \mathrm{~N}$-Sieber amide resin by an Advanced ChemTech multiple-peptide synthesizer. The protecting group of Dde was removed by $2 \%$ hydrazine for peptide cyclization. The protecting group of 2-phenylisopropyl from the Asp residue was removed, and the protected peptide was cleaved from the resin by treatment with a mixture of $2.5 \%$ of trifluoroacetic acid (TFA) and 5\% of triisopropylsilane for $1 \mathrm{~h}$. After precipitation with ice-cold ether and characterization by liquid chromatographymass spectroscopy (LC-MS), the protected peptide was dissolved in $\mathrm{H}_{2} \mathrm{O}: \mathrm{CH}_{3} \mathrm{CN}$ (30:70) and lyophilized to remove the reagents such as TFA and triisopropylsilane. The protected peptide was further cyclized by coupling the carboxylic group from the Asp with the $\varepsilon$-amino group from the Lys. The cyclization reaction was achieved by an overnight reaction in dimethylformamide using benzotriazole1-yl-oxy-tris-pyrrolidino-phosphonium-hexafluorophosphate as a coupling agent in the presence of $N, N$-diisopropylethylamine. After characterization by LC-MS, the cyclized protected peptide was dissolved in $\mathrm{H}_{2} \mathrm{O}: \mathrm{CH}_{3} \mathrm{CN}$ (30:70) and lyophilized to remove the reagents such as benzotriazole-1-yl-oxy-tris-pyrrolidino-phosphonium-hexafluorophosphate and $N, N$-diisopropylethylamine. The protecting groups were totally removed by treatment with a mixture of TFA, thioanisole, phenol, water, ethanedithiol, and triisopropylsilane $(87.5: 2.5: 2.5: 2.5: 2.5: 2.5)$ for $4 \mathrm{~h}$ at room temperature $\left(25^{\circ} \mathrm{C}\right)$. The peptide was precipitated and washed with ice-cold ether 4 times, purified by reversed-phase (RP) high-performance liquid chromatography (HPLC), and characterized by LC-MS.

\section{In Vitro Competitive Binding Assay}

The inhibitory concentration of $50 \%\left(\mathrm{IC}_{50}\right)$ value of DOTA-

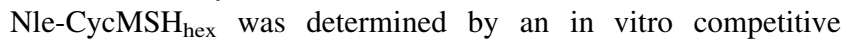
binding assay according to our previously published procedure (21). B16/F1 cells were harvested and seeded into a 24-well cell culture plate $\left(5 \times 10^{5}\right.$ cells per well $)$ and incubated at $37^{\circ} \mathrm{C}$ overnight. After the cells were washed twice with binding medium, Dulbecco's modified Eagle's medium with $25 \mathrm{mM}$ $N$-(2-hydroxyethyl)-piperazine- $N$-(2-ethanesulfonic acid) $\quad(\mathrm{pH}$ $7.4,0.2 \%$ bovine serum albumin [BSA], and $0.3 \mathrm{mM} 1,10-$ phenathroline), they were incubated at room temperature $\left(25^{\circ} \mathrm{C}\right)$ for $2 \mathrm{~h}$ with approximately 60,000 counts per minute of ${ }^{125} \mathrm{I}_{-} \mathrm{Tyr}^{2}$ NDP-MSH in the presence of increasing concentrations $\left(10^{-12}\right.$ to $10^{-5} \mathrm{M}$ ) of DOTA-Nle-CycMSH $\mathrm{Hex}_{\text {in }} 0.3 \mathrm{~mL}$ of binding medium. The reaction medium was aspirated after the incubation. The cells were rinsed twice with $0.5 \mathrm{~mL}$ of ice-cold, $\mathrm{pH} 7.4,0.2 \% \mathrm{BSA} / 0.01$ $\mathrm{M}$ phosphate-buffered saline and lysed in $0.5 \mathrm{~mL}$ of $1 \mathrm{~N} \mathrm{NaOH}$ for $5 \mathrm{~min}$. The activities associated with cells were measured in a Wallac 1480 automated $\gamma$-counter (PerkinElmer). The $\mathrm{IC}_{50}$ value of the peptide was calculated using Prism software (GraphPad Software).

\section{Peptide Radiolabeling with ${ }^{111}$ In}

${ }^{111} \mathrm{In}$-DOTA-Nle-CycMSH $\mathrm{Chx}_{\text {hex }}$ was prepared in a $0.5 \mathrm{M}$ $\mathrm{NH}_{4} \mathrm{OAc}$-buffered solution at $\mathrm{pH} 4.5$ according to our published procedure (21). Briefly, $50 \mu \mathrm{L}$ of ${ }^{111} \mathrm{InCl}_{3}(37-74 \mathrm{MBq}$ [1-2 mCi] in $0.05 \mathrm{M} \mathrm{HCl}$ aqueous solution), $10 \mu \mathrm{L}$ of a $1 \mathrm{mg} / \mathrm{mL}$ aqueous solution of DOTA-Nle-CycMSH hex , and $400 \mu \mathrm{L}$ of $0.5 \mathrm{M}$ $\mathrm{NH}_{4} \mathrm{OAc}(\mathrm{pH} 4.5)$ were added into a reaction vial and incubated at $75^{\circ} \mathrm{C}$ for $45 \mathrm{~min}$. After the incubation, $10 \mu \mathrm{L}$ of $0.5 \%$ ethylenediaminetetraacetic acid aqueous solution were added into the reaction vial to scavenge potential unbound ${ }^{111} \mathrm{In}^{3+}$ ions. The radiolabeled peptide was purified to a single species by Waters RP HPLC on a Grace Vydac C-18 reversed-phase analytic column using a 20 -min gradient of $18 \%-28 \%$ acetonitrile in $20 \mathrm{mM} \mathrm{HCl}$ aqueous solution with a flow rate of $1.0 \mathrm{~mL} / \mathrm{min}$. The purified peptide sample was purged with $\mathrm{N}_{2}$ gas for $20 \mathrm{~min}$ to remove the acetonitrile. The $\mathrm{pH}$ of the final solution was adjusted to 7.4 with $0.1 \mathrm{~N} \mathrm{NaOH}$ and sterile normal saline for animal studies. The in vitro serum stability of HPLC-purified ${ }^{111}$ In-DOTA-Nle-Cy$\mathrm{cMSH}_{\text {hex }}$ was determined by incubation in mouse serum at $37^{\circ} \mathrm{C}$ for $24 \mathrm{~h}$ and monitored for degradation by RP HPLC.

\section{Cellular Internalization and Efflux of \\ ${ }^{111}$ In-DOTA-Nle-CycMSH ${ }_{\text {hex }}$}

Cellular internalization and efflux of ${ }^{111}$ In-DOTA-Nle-Cy$\mathrm{cMSH}_{\text {hex }}$ were evaluated in B16/F1 melanoma cells. After being 
washed twice with the binding medium, the B16/F1 cells seeded in cell culture plates were incubated at $25^{\circ} \mathrm{C}$ for $20,40,60,90$, and $120 \min (n=3)$ in the presence of approximately 200,000 counts per minute of HPLC-purified ${ }^{111}$ In-DOTA-Nle-CycMSH $\mathrm{Hex}_{\text {hex }}$ After incubation, the reaction medium was aspirated, and the cells were rinsed with $2 \times 0.5 \mathrm{~mL}$ of ice-cold, $\mathrm{pH} 7.4,0.2 \% \mathrm{BSA} / 0.01 \mathrm{M}$ phosphate-buffered saline. Cellular internalization of ${ }^{111}$ InDOTA-Nle-CycMSH $\mathrm{Hex}_{\text {has }}$ assessed by washing the cells with acidic buffer $(40 \mathrm{mM}$ sodium acetate [pH 4.5] containing $0.9 \%$ $\mathrm{NaCl}$ and $0.2 \%$ BSA) to remove the membrane-bound radioactivity. The remaining internalized radioactivity was obtained by lysing the cells with $0.5 \mathrm{~mL}$ of $1 \mathrm{~N} \mathrm{NaOH}$ for $5 \mathrm{~min}$. Membranebound and internalized ${ }^{111} \mathrm{In}$ activities were counted in a $\gamma$-counter. Cellular efflux of ${ }^{111}$ In-DOTA-Nle-CycMSH $\mathrm{MSx}_{\text {hex }}$ was determined by incubating the B16/F1 cells with ${ }^{111}$ In-DOTA-Nle-CycMSH ${ }_{\text {hex }}$ for $2 \mathrm{~h}$ at $25^{\circ} \mathrm{C}$, removing nonspecifically bound activity with $2 \times$ $0.5 \mathrm{~mL}$ of ice-cold phosphate-buffered saline rinse, and monitoring radioactivity released into the cell culture medium. At 20, 40, 60,90 , and $120 \mathrm{~min}$, the radioactivities on the cell surface and inside the cells were separately collected and counted in a $\gamma$-counter.

\section{Biodistribution Studies}

All the animal studies were conducted in compliance with Institutional Animal Care and Use Committee approval. The mice were housed 5 animals per cage in sterile microisolator cages in a temperature- and humidity-controlled room with a 12-h light/12$\mathrm{h}$ dark schedule. The pharmacokinetics of ${ }^{111}$ In-DOTA-Nle$\mathrm{CycMSH}_{\text {hex }}$ were determined in B16/F1 melanoma-bearing C57 female mice (Harlan). C57 mice were subcutaneously inoculated on the right flank with $1 \times 10^{6} \mathrm{~B} 16 / \mathrm{F} 1$ cells. The weight of tumors reached approximately $0.2 \mathrm{~g} 10 \mathrm{~d}$ after cell inoculation. Each melanoma-bearing mouse was injected with $0.037 \mathrm{MBq}(1 \mu \mathrm{Ci})$ of ${ }^{111} \mathrm{In}-\mathrm{DOTA}-\mathrm{Nle}-\mathrm{CycMSH}_{\text {hex }}$ via the tail vein. Groups of 5 mice were sacrificed at $0.5,2,4$, and $24 \mathrm{~h}$ after injection, and tumors and organs of interest were harvested, weighed, and counted. Blood values were taken as $6.5 \%$ of the whole-body weight. The tumor uptake specificity of ${ }^{111}$ In-DOTA-Nle-CycMSH ${ }_{\text {hex }}$ was determined by coinjecting $10 \mu \mathrm{g}$ of unlabeled NDP-MSH, a linear $\alpha$-MSH peptide analog with picomolar affinity for the MC1 receptor present on the melanoma cells. To examine whether L-lysine coinjection can reduce the renal uptake, a group of 5 mice was injected with a mixture of $12 \mathrm{mg}$ of L-lysine and 0.037 $\mathrm{MBq}(1 \mu \mathrm{Ci})$ of ${ }^{111} \mathrm{In}-\mathrm{DOTA}-\mathrm{Nle}-\mathrm{CycMSH}_{\text {hex. }}$ The mice were sacrificed at $2 \mathrm{~h}$ after injection. The tumor and organs of interest were harvested, weighed, and counted.

\section{Melanoma Imaging with ${ }^{111}$ In-DOTA-Nle-CycMSH hex $_{\text {n }}$}

Two B16/F1 melanoma-bearing C57 mice (10 d after the cell inoculation) were injected with $37 \mathrm{MBq}(1 \mathrm{mCi})$ of ${ }^{111}$ In-DOTANle-CycMSH $\mathrm{Hex}_{\text {hex }}$ via the tail vein. The mice were sacrificed for small-animal SPECT/CT (Nano-SPECT/CT; Bioscan) at 2 and 24 $\mathrm{h}$ after injection. The 9-min CT scan was immediately followed by the whole-body SPECT scan. The SPECT scans of 24 projections were acquired, and total acquisition time was approximately 60 min. Reconstructed data from SPECT and CT were visualized and coregistered using InVivoScope (Bioscan).

\section{Urinary Metabolites of ${ }^{111}$ In-DOTA-Nle-CycMSH ${ }_{\text {hex }}$}

The mouse used for the imaging study ( $2 \mathrm{~h}$ after injection) was euthanized, and the urine was collected for identification of the metabolites. The urinary sample was centrifuged at $16,000 g$ for 5 min before the HPLC analysis. The radioactive metabolite in the urine was analyzed by injecting aliquots of urine into the chomatograph. A 20-min gradient of $18 \%-28 \%$ acetonitrile/20 $\mathrm{mM} \mathrm{HCl}$ was used for the urine analysis.

\section{Statistical Analysis}

Statistical analysis was performed using the Student $t$ test for unpaired data. A 95\% confidence level was chosen to determine the significance between the tumor uptake of ${ }^{111}$ In-DOTA-Nle$\mathrm{CycMSH}_{\text {hex }}$ with or without NDP-MSH coinjection and the renal uptake of ${ }^{111} \mathrm{In}$-DOTA-Nle-CycMSH $\mathrm{Hex}_{\text {hex }}$ with or without L-lysine coinjection in the biodistribution studies described earlier. Differences at the $95 \%$ confidence level $(P<0.05)$ were considered significant.

\section{RESULTS}

To examine the profound effect of peptide ring size on melanoma and kidney uptake of the ${ }^{111}$ In-labeled lactam bridge-cyclized $\alpha$-MSH peptide, a novel peptide of DOTANle-CycMSH $\mathrm{Mhx}_{\text {has }}$ synthesized and purified by RP HPLC. The identity of the peptide was confirmed by electrospray ionization mass spectrometry (molecular weight, 1,368.5; calculated molecular weight, 1,368.2). DOTA-Nle-CycMSH $\mathrm{Hex}_{\text {hex }}$ displayed greater than $95 \%$ purity, with $30 \%$ overall synthetic yield. The schematic structures

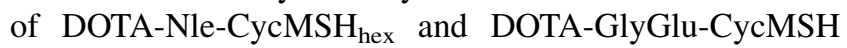
are shown in Figure 1. Figure 2 illustrates the synthetic

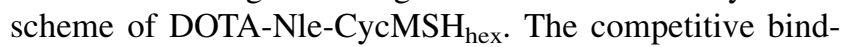
ing curve of DOTA-Nle-CycMSH $\mathrm{Hex}_{\text {is }}$ isesented in Figure $3 \mathrm{~A}$. The $\mathrm{IC}_{50}$ value of DOTA-Nle-CycMSH $\mathrm{hex}_{\text {was }} 1.77 \mathrm{nM}$ in B16/F1 cells.

The peptide was readily labeled with ${ }^{111} \mathrm{In}$ in $0.5 \mathrm{M}$ ammonium acetate at $\mathrm{pH} 4.5$ with greater than $95 \%$ radiolabeling yield. ${ }^{111}$ In-DOTA-Nle-CycMSH $\mathrm{MSx}_{\text {hex }}$ was completely separated from its excess nonlabeled peptide by RP HPLC. The retention time of ${ }^{111} \mathrm{In}-\mathrm{DOTA}-\mathrm{Nle}-\mathrm{CycMSH}_{\text {hex }}$ was 10.7 min. ${ }^{111}$ In-DOTA-Nle-CycMSH ${ }_{\text {hex }}$ showed greater than $98 \%$ radiochemical purity after the HPLC purification. ${ }^{111} \mathrm{In}-$ DOTA-Nle-CycMSH $\mathrm{MS}_{\text {hex }}$ was stable in mouse serum at $37^{\circ} \mathrm{C}$ for $24 \mathrm{~h}$. Only the ${ }^{111}$ In-DOTA-Nle-CycMSH $\mathrm{CH}_{\text {hex }}$ was detected by RP HPLC after $24 \mathrm{~h}$ of incubation.

Cellular internalization and efflux of ${ }^{111}$ In-DOTA-Nle$\mathrm{CycMSH}_{\text {hex }}$ were evaluated in B16/F1 cells. Figures 3B and $3 \mathrm{C}$ illustrate the cellular internalization and efflux of ${ }^{111}$ In-DOTA-Nle-CycMSH ${ }_{\text {hex }}$, respectively. ${ }^{111}$ In-DOTANle-CycMSH$H_{\text {hex }}$ exhibited rapid cellular internalization and extended cellular retention. At 20 and $120 \mathrm{~min}$ after incubation, $72.9 \% \pm 3.5 \%$ and $88.3 \% \pm 0.7 \%$, respectively, of the cellular uptake of ${ }^{111}$ In-DOTA-Nle-CycMSH ${ }_{\text {hex }}$ activity had internalized in the B16/F1 cells. Cellular efflux results demonstrated that $89.5 \% \pm 1.9 \%$ of internalized ${ }^{111}$ InDOTA-Nle-CycMSH $\mathrm{MH}_{\text {ex }}$ activity remained inside the cells $2 \mathrm{~h}$ after the cells were incubated in culture medium.

The melanoma-targeting and pharmacokinetic properties

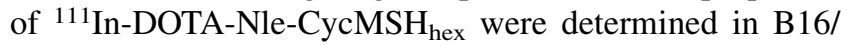
F1 melanoma-bearing C57 mice. The biodistribution results of ${ }^{111}$ In-DOTA-Nle-CycMSH $\mathrm{Hex}_{\text {he }}$ are shown in Table 1. 


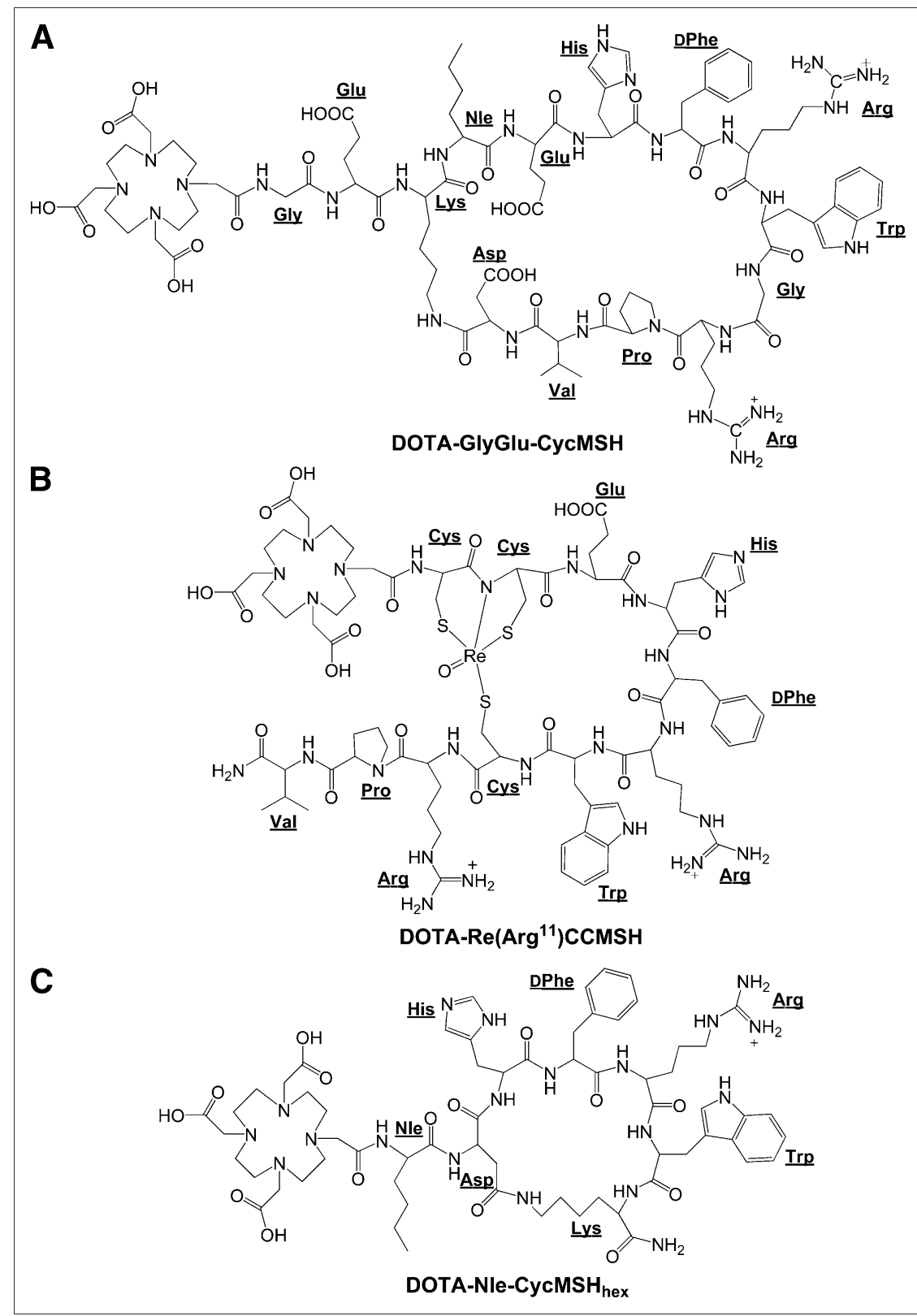

FIGURE 1. Structures of DOTA-GlyGluCycMSH (A), DOTA-Re(Arg $\left.{ }^{11}\right) \mathrm{CCMSH}$ (B), and DOTA-Nle-CycMSH hex (C).
${ }^{111}$ In-DOTA-Nle-CycMSH $\mathrm{Hex}_{\text {ex }}$ exhibited rapid high melanoma uptake and prolonged tumor retention in melanoma-bearing mice. At $0.5 \mathrm{~h}$ after injection, ${ }^{111} \mathrm{In}-\mathrm{DOTA}-\mathrm{Nle}-\mathrm{CycMSH}_{\mathrm{hex}}$ reached its peak tumor uptake of $24.94 \pm 4.58 \% \mathrm{ID} / \mathrm{g}$. At 4 and $24 \mathrm{~h}$ after injection, $17.01 \pm 2.54 \% \mathrm{ID} / \mathrm{g}$ and $10.53 \pm$ $1.11 \% \mathrm{ID} / \mathrm{g}$ of the ${ }^{111} \mathrm{In}-\mathrm{DOTA}-\mathrm{Nle}-\mathrm{CycMSH}_{\text {hex }}$ activity, respectively, remained in the tumors. In the melanoma uptake blocking study, the tumor uptake of ${ }^{111}$ In-DOTANle-CycMSH $\mathrm{Hex}_{\text {ex }}$ with $10 \mu \mathrm{g}$ of nonradiolabeled NDP-MSH coinjection was only $4.2 \%$ of the tumor uptake without NDP-MSH coinjection at $2 \mathrm{~h}$ after dose administration $(P<$ $0.05)$, demonstrating that the tumor uptake was specific and $\mathrm{MC1}$ receptor-mediated. Whole-body clearance of ${ }^{111} \mathrm{In}$ DOTA-Nle-CycMSH $\mathrm{Mex}_{\text {has }}$ rapid, with approximately $82 \%$ of the injected radioactivity cleared through the urinary system by $2 \mathrm{~h}$ after injection (Table 1 ). Normal-organ uptake of ${ }^{111} \mathrm{In}-\mathrm{DOTA}-\mathrm{Nle}-\mathrm{CycMSH}_{\text {hex }}$ was low $(<1.89 \% \mathrm{ID} / \mathrm{g})$, except for the kidneys, at 2, 4, and $24 \mathrm{~h}$ after injection. High tumor-to-blood and high tumor-to-normal-organ uptake ratios were achieved as early as $0.5 \mathrm{~h}$ after injection (Table 1 ). As the major excretion pathway of ${ }^{111}$ In-DOTA-Nle$\mathrm{CycMSH}_{\text {hex }}$, the kidney uptake was $16.20 \pm 4.32 \% \mathrm{ID} / \mathrm{g}$ at $0.5 \mathrm{~h}$ after injection and decreased to $9.31 \pm 0.91 \% \mathrm{ID} / \mathrm{g}$ at $24 \mathrm{~h}$ after injection. The tumor-to-kidney uptake ratios of

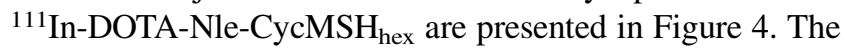
tumor-to-kidney uptake ratios of ${ }^{111}$ In-DOTA-Nle-Cy$\mathrm{cMSH}_{\text {hex }}$ were 2.04, 1.70, and 1.13 at 2, 4, and $24 \mathrm{~h}$, respectively, after injection. Coinjection of NDP-MSH did not reduce renal uptake of ${ }^{111}$ In-DOTA-Nle-CycMSH ${ }_{\text {hex }}$ activity at $2 \mathrm{~h}$ after injection, indicating that renal uptake 
$\mathrm{H}_{2} \mathrm{~N}$-Sieber amide resin

1) Standard Fmoc synthesis

2) Coupling of (tBu) $)_{3}$ DOTA

$(\mathrm{tBu})_{3} \mathrm{DOTA}-\mathrm{Nle}-\mathrm{Asp}(\mathrm{O}-2-\mathrm{PhiPr})-\mathrm{His}(\mathrm{Trt})-\mathrm{DPhe}$ $\operatorname{Arg}(\mathrm{Pbf})-\mathrm{Trp}(\mathrm{Boc})$-Lys(Dde)-resin

$$
\begin{aligned}
& \text { 1) } 2 \% \text { Hydrazine } \\
& \text { 2) } 2.5 \% \text { TFA } \\
& \text { 3) PyBop, DIEA }
\end{aligned}
$$

(tBu) ${ }_{3}$ DOTA-Nle-Asp-His(Trt)-DPhe

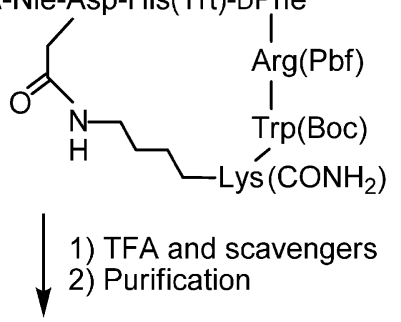

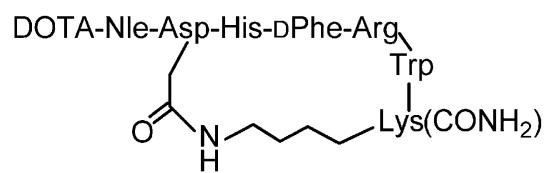

DOTA-Nle-CycMSH ${ }_{\text {hex }}$

FIGURE 2. Synthetic scheme of DOTA-Nle-CycMSH $\mathrm{H}_{\text {hex }}$

was not MC1 receptor-mediated. Coinjection of L-lysine significantly $(P<0.05)$ reduced kidney uptake by $30 \%$ at $2 \mathrm{~h}$ after injection (Table 1).

Two B16/F1 melanoma-bearing C57 mice were separately injected with $37 \mathrm{MBq}(1 \mathrm{mCi})$ of ${ }^{111} \mathrm{In}$-DOTA-Nle$\mathrm{CycMSH}_{\text {hex }}$ through the tail vein to visualize the tumors at 2 and $24 \mathrm{~h}$ after dose administration. The whole-body SPECT/CT images are presented in Figures $5 \mathrm{~A}$ and 5B. Flank melanoma tumors were clearly visualized by SPECT/CT at 2 and $24 \mathrm{~h}$ after injection of ${ }^{111}$ In-DOTANle-CycMSH $\mathrm{CH}_{\text {hex }}$. In agreement with the biodistribution results, both images showed high tumor-to-normal-organ uptake ratios except for the kidneys. The urinary metabolite of ${ }^{111} \mathrm{In}$-DOTA-Nle-CycMSH $\mathrm{Hex}_{\text {was }}$ analyzed by RP HPLC at $2 \mathrm{~h}$ after injection. Figure 5C illustrates the urinary HPLC profile of ${ }^{111}$ In-DOTA-Nle-CycMSH ${ }_{\text {hex }}$. ${ }^{111} \mathrm{In}$-DOTA-Nle-CycMSH $\mathrm{H}_{\text {hex }}$ remained intact in the urine $2 \mathrm{~h}$ after injection.

\section{DISCUSSION}

Cyclization strategies using a disulfide bridge, a lactam bridge, and metal coordination have been successfully applied to cyclize the $\alpha$-MSH peptides to enhance the binding affinities and in vivo stabilities of the peptides (23-26). Both ${ }^{111}$ In-labeled metal-cyclized and lactam
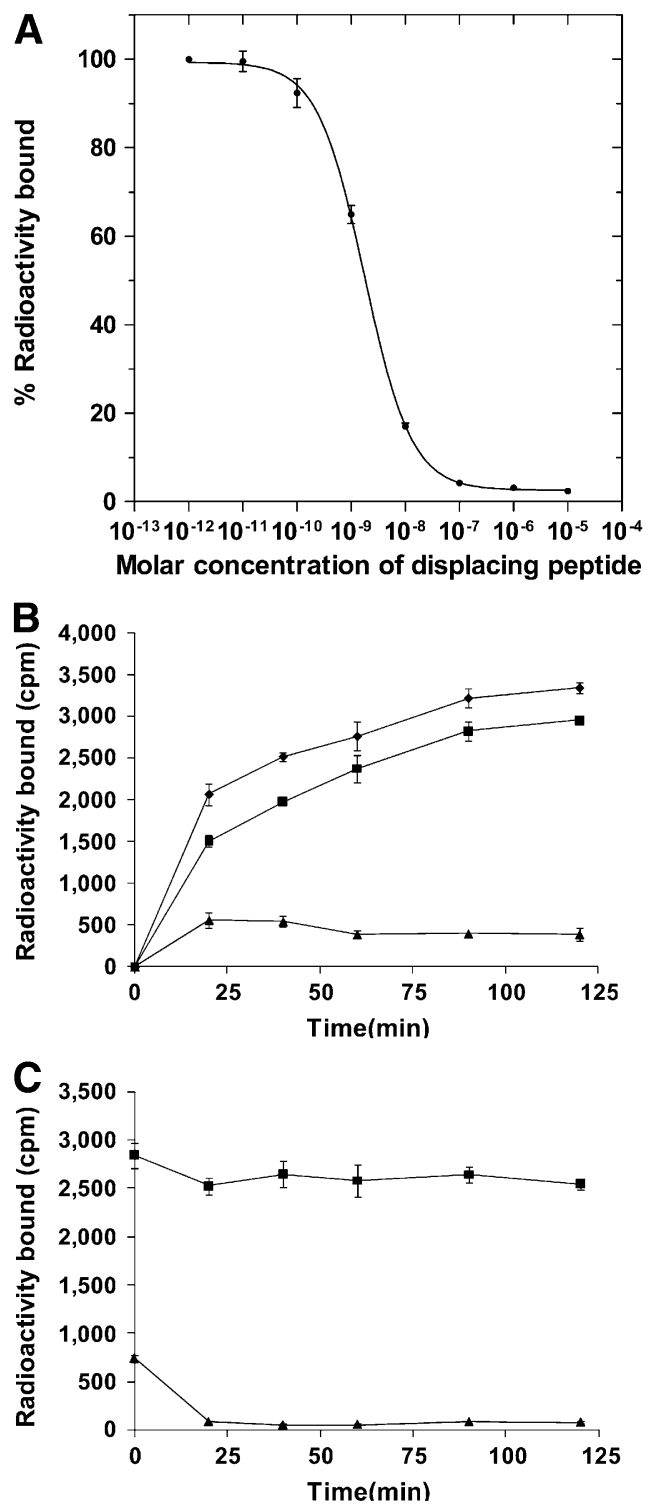

FIGURE 3. Competitive binding curve (A) of DOTA-Nle$\mathrm{CycMSH}_{\text {hex }}$ in B16/F1 melanoma cells. $\mathrm{IC}_{50}$ value of DOTANle-CycMSH $\mathrm{H}_{\text {hex }}$ was $1.77 \mathrm{nM}$. Cellular internalization (B) and efflux (C) of ${ }^{111} \mathrm{In}-\mathrm{DOTA}-\mathrm{Nle}-\mathrm{CycMSH}_{\text {hex }}$ in B16/F1 melanoma cells at $25^{\circ} \mathrm{C}$. Total bound radioactivity $(\bullet)$, internalized activity $(\boldsymbol{\nabla})$, and cell membrane activity $(\boldsymbol{\Delta})$ were presented as counts per minute (cpm).

bridge-cyclized $\alpha$-MSH peptides exhibited greater melanoma uptake and lower renal uptake than ${ }^{111}$ In-labeled disulfide bridge-cyclized $\alpha$-MSH peptide $(21,29)$. We have reported a novel class of melanoma-specific ${ }^{111}$ In-labeled lactam bridge-cyclized $\alpha$-MSH peptides for both primary and metastatic melanoma imaging $(21,22)$. ${ }^{111}$ In-DOTAGlyGlu-CycMSH (Fig. 1), with a 12-amino acid peptide 
TABLE 1. Biodistribution of ${ }^{111}$ In-DOTA-Nle-CycMSH ${ }_{\text {hex }}$ in B16/F1 Melanoma-Bearing C57 Mice

\begin{tabular}{|c|c|c|c|c|c|c|}
\hline \multirow[b]{2}{*}{ Tissue } & \multicolumn{6}{|c|}{ Biodistribution at... } \\
\hline & $0.5 \mathrm{~h}$ & $2 \mathrm{~h}$ & $4 \mathrm{~h}$ & $24 \mathrm{~h}$ & $\begin{array}{l}\text { 2-h NDP } \\
\text { blockade }\end{array}$ & $\begin{array}{l}\text { 2-h L-lysine } \\
\text { coinjection }\end{array}$ \\
\hline \multicolumn{7}{|l|}{$\% \mid D / g^{*}$} \\
\hline Tumor & $24.94 \pm 4.58$ & $19.39 \pm 1.65$ & $17.01 \pm 2.54$ & $10.53 \pm 1.11$ & $0.81 \pm 0.03^{\dagger}$ & $14.48 \pm 3.25$ \\
\hline Brain & $0.21 \pm 0.07$ & $0.02 \pm 0.01$ & $0.06 \pm 0.03$ & $0.03 \pm 0.01$ & $0.01 \pm 0.01$ & $0.04 \pm 0.01$ \\
\hline Blood & $3.33 \pm 0.35$ & $0.11 \pm 0.07$ & $0.05 \pm 0.02$ & $0.02 \pm 0.01$ & $0.07 \pm 0.05$ & $0.92 \pm 0.48$ \\
\hline Heart & $1.24 \pm 0.15$ & $0.16 \pm 0.10$ & $0.12 \pm 0.03$ & $0.07 \pm 0.05$ & $0.06 \pm 0.02$ & $0.37 \pm 0.02$ \\
\hline Lung & $2.45 \pm 0.83$ & $0.32 \pm 0.10$ & $0.10 \pm 0.05$ & $0.10 \pm 0.03$ & $0.30 \pm 0.06$ & $0.75 \pm 0.21$ \\
\hline Liver & $2.75 \pm 0.26$ & $1.46 \pm 0.20$ & $1.72 \pm 0.07$ & $1.89 \pm 0.14$ & $1.46 \pm 0.08$ & $1.42 \pm 0.30$ \\
\hline Spleen & $1.09 \pm 0.33$ & $0.41 \pm 0.13$ & $0.47 \pm 0.13$ & $0.32 \pm 0.08$ & $0.44 \pm 0.02$ & $0.43 \pm 0.07$ \\
\hline Stomach & $3.20 \pm 0.98$ & $1.25 \pm 0.24$ & $1.49 \pm 0.12$ & $1.34 \pm 0.42$ & $0.36 \pm 0.14$ & $1.64 \pm 0.78$ \\
\hline Kidneys & $16.20 \pm 4.32$ & $9.52 \pm 0.44$ & $9.99 \pm 1.39$ & $9.31 \pm 0.91$ & $11.56 \pm 0.56$ & $6.66 \pm 0.62^{\dagger}$ \\
\hline Muscle & $0.60 \pm 0.22$ & $0.15 \pm 0.08$ & $0.10 \pm 0.08$ & $0.03 \pm 0.01$ & $0.02 \pm 0.01$ & $0.10 \pm 0.08$ \\
\hline Pancreas & $1.18 \pm 0.38$ & $0.14 \pm 0.02$ & $0.16 \pm 0.02$ & $0.23 \pm 0.08$ & $0.12 \pm 0.02$ & $0.21 \pm 0.05$ \\
\hline Bone & $1.34 \pm 0.40$ & $0.18 \pm 0.10$ & $0.22 \pm 0.15$ & $0.16 \pm 0.03$ & $0.05 \pm 0.04$ & $0.55 \pm 0.14$ \\
\hline Skin & $4.11 \pm 0.72$ & $0.66 \pm 0.23$ & $0.53 \pm 0.05$ & $0.64 \pm 0.16$ & $0.29 \pm 0.02$ & $1.02 \pm 0.09$ \\
\hline \multicolumn{7}{|l|}{$\% \mathrm{ID}^{*}$} \\
\hline Intestines & $2.16 \pm 0.28$ & $1.40 \pm 0.56$ & $3.03 \pm 1.06$ & $1.41 \pm 0.86$ & $1.14 \pm 0.47$ & $1.85 \pm 0.73$ \\
\hline Urine & $57.00 \pm 3.91$ & $82.23 \pm 5.83$ & $84.61 \pm 5.21$ & $87.29 \pm 3.60$ & $92.25 \pm 1.56$ & $76.79 \pm 5.35$ \\
\hline \multicolumn{7}{|c|}{$\begin{array}{l}\text { Tumor-to-normal-tissue } \\
\text { uptake ratio }\end{array}$} \\
\hline Tumor-to-blood & 7.49 & 176.27 & 340.20 & 526.50 & 11.57 & 15.74 \\
\hline Tumor-to-kidneys & 1.54 & 2.04 & 1.70 & 1.13 & 0.07 & 2.17 \\
\hline Tumor-to-lung & 10.18 & 60.59 & 170.10 & 105.30 & 2.70 & 19.31 \\
\hline Tumor-to-liver & 9.07 & 13.28 & 9.89 & 5.57 & 0.55 & 10.20 \\
\hline Tumor-to-muscle & 41.57 & 129.27 & 170.10 & 351.00 & 40.50 & 144.80 \\
\hline Tumor-to-skin & 6.07 & 29.38 & 32.09 & 16.45 & 2.79 & 14.20 \\
\hline $\begin{array}{r}{ }^{*} \text { Mean } \pm \text { SD }(n=5 \\
\quad P<0.05, \text { significa } \\
\text { kidney uptake of }{ }^{111} \mathrm{In}- \\
\text { Data are presented }\end{array}$ & $\begin{array}{l}\text { nparison betw } \\
\text { Nle-CycMSH } \\
\text { cent \%ID/g or }\end{array}$ & $\begin{array}{l}\text { tumor uptake } \\
\text { ith or without } \\
\% \text { ID (mean } \pm\end{array}$ & $\begin{array}{l}{ }^{111} \text { In-DOTA-I } \\
\text { ysine coinjec } \\
, n=5)\end{array}$ & $\mathrm{CycMSH}_{\text {hex }} \mathrm{W}$ & without NDP & H blockade and \\
\hline
\end{tabular}

ring, exhibited great potential as a melanoma-specific imaging probe in detecting both primary and metastatic melanoma lesions $(21,22)$. However, tumor uptake of ${ }^{111}$ In-DOTA-GlyGlu-CycMSH was $60.15 \%$ that of ${ }^{111} \mathrm{In}-$

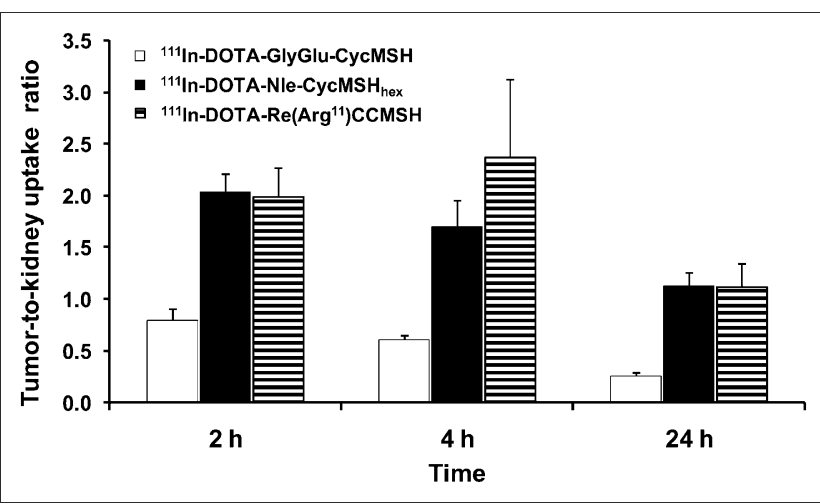

FIGURE 4. Tumor-to-kidney uptake ratios of ${ }^{111} \mathrm{In}$-DOTAGlyGlu-CycMSH, ${ }^{111}$ In-DOTA-Nle-CycMSH ${ }_{\text {hex }}$, and ${ }^{111}$ InDOTA-Re(Arg $\left.{ }^{11}\right) \mathrm{CCMSH}$ at 2, 4, and $24 \mathrm{~h}$ after injection. Calculated tumor-to-kidney uptake ratios of ${ }^{111} \mathrm{In}$-DOTAGlyGlu-CycMSH and ${ }^{111} \mathrm{In}-\mathrm{DOTA}-\mathrm{Re}\left(\mathrm{Arg}^{11}\right) \mathrm{CCMSH}$ were based on results published by Cheng et al. (17) and Miao et al. (21).
DOTA-Re $\left(\operatorname{Arg}{ }^{11}\right) \mathrm{CCMSH}$, whereas kidney uptake of ${ }^{111} \mathrm{In}$ DOTA-GlyGlu-CycMSH was 1.5 times renal uptake of ${ }^{111} \mathrm{In}-\mathrm{DOTA}-\mathrm{Re}\left(\mathrm{Arg}^{11}\right) \mathrm{CCMSH}$ at $2 \mathrm{~h}$ after injection in B16/F1 melanoma-bearing C57 mice $(17,21)$. The structural differences between ${ }^{111}$ In-DOTA-GlyGlu-CycMSH and ${ }^{111}$ In-DOTA-Re( $\left(\operatorname{Arg}^{11}\right)$ CCMSH (Fig. 1) indicated that the smaller size of the peptide ring might contribute to the more favorable melanoma targeting and pharmacokinetic properties of ${ }^{111} \mathrm{In}$-DOTA-Re( $\left(\mathrm{Arg}^{11}\right) \mathrm{CCMSH}$ because there was an 8-amino acid peptide ring in ${ }^{111}$ In-DOTA$\operatorname{Re}\left(\operatorname{Arg}{ }^{11}\right) C C M S H$, whereas there was a 12 -amino acid peptide ring in ${ }^{111}$ In-DOTA-GlyGlu-CycMSH. Moreover, it was reported that the lactam bridge-cyclized $\alpha$-MSH peptide with a 6-amino acid peptide ring (Ac-Nle-c[AspHis-D-Phe-Arg-Trp-Lys $\left.\left(\mathrm{CONH}_{2}\right)\right]$ ) displayed not only higher $\mathrm{MC} 1$ receptor-binding affinity but also a slower $\mathrm{MC} 1$ receptor dissociation rate than the native $\alpha$-MSH peptide (27). Therefore, we synthesized a novel DOTAconjugated lactam bridge-cyclized peptide with a 6-amino acid peptide ring (DOTA-Nle-CycMSH ${ }_{\text {hex }}$ ) to examine the profound effect of the peptide ring size on the tumor and kidney uptake in this study.

The conjugation of DOTA to the $\mathrm{N}$ terminus of the peptide and the reduction of the peptide ring size did not 


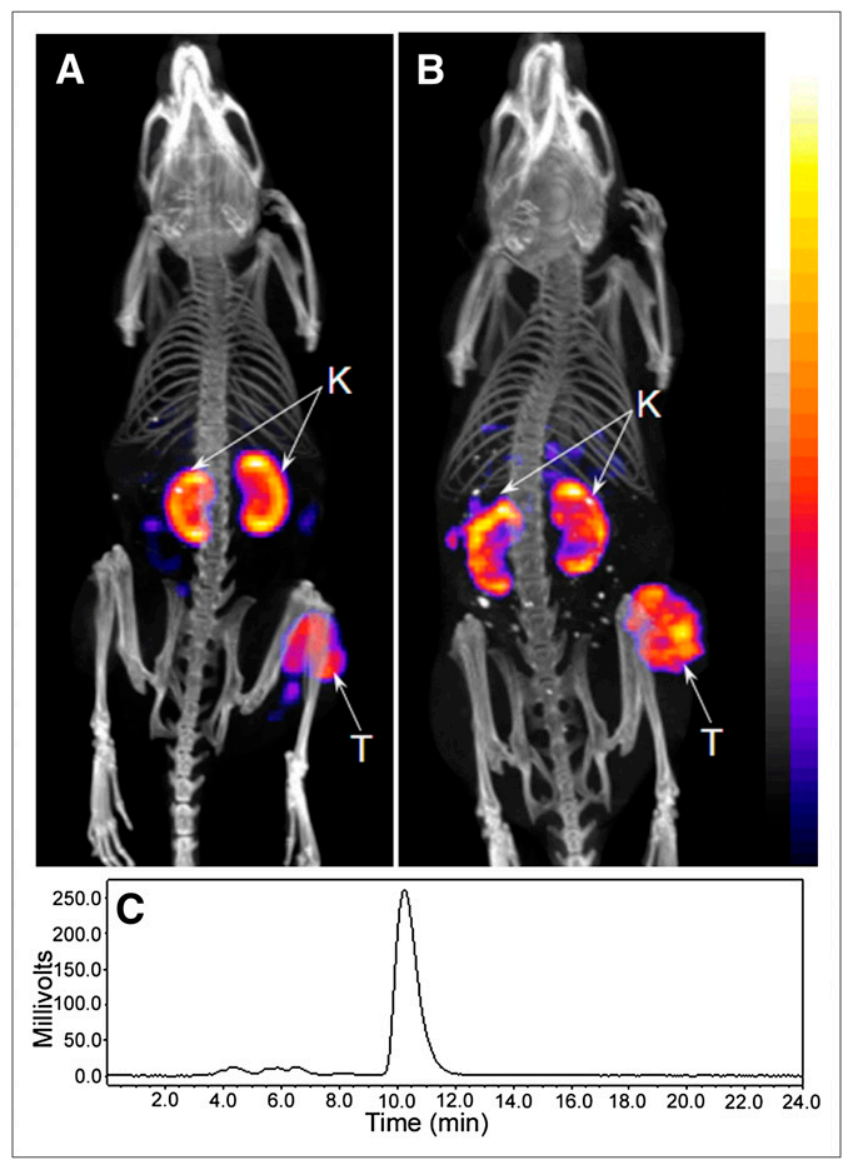

FIGURE 5. Whole-body SPECT/CT images of B16/F1 flank melanoma-bearing C57 mice at 2 (A) and $24 \mathrm{~h}(\mathrm{~B})$ after injection of $37 \mathrm{MBq}(1 \mathrm{mCi})$ of ${ }^{111} \mathrm{In}-\mathrm{DOTA}-\mathrm{Nle}-\mathrm{CycMSH}_{\text {hex. }}$. Tumor $(\mathrm{T})$ and kidneys $(\mathrm{K})$ are highlighted with arrows on images. HPLC profile (C) of radioactive urine sample of B16/ $\mathrm{F} 1$ melanoma-bearing $\mathrm{C} 57$ mouse at $2 \mathrm{~h}$ after injection of ${ }^{111}$ In-DOTA-Nle-CycMSH hex. $^{111}$ In-DOTA-Nle-CycMSH $\mathrm{H}_{\text {hex }}$ remained intact in urine at $2 \mathrm{~h}$ after injection.

sacrifice the MC1 receptor-binding affinity of DOTA-Nle$\mathrm{CycMSH}_{\text {hex }}$. DOTA-Nle-CycMSH hex exhibited $1.77 \mathrm{nM}$ MC1 receptor-binding affinity in B16/F1 melanoma cells (Fig. 3A), whereas DOTA-GlyGlu-CycMSH and DOTA$\operatorname{Re}\left(\operatorname{Arg}^{11}\right)$ CCMSH displayed 0.90 and $2.10 \mathrm{nM} \mathrm{MC} 1$ receptor-binding affinities in B16/F1 cells $(17,21) .{ }^{111} \mathrm{In}-$

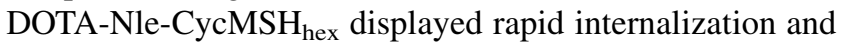
prolonged retention in B16/F1 melanoma cells, highlighting its potential as an effective imaging probe for melanoma detection and a therapeutic agent for melanoma treatment when labeled with a therapeutic radionuclide. As we anticipated, the strategy of reducing the ring size of the lactam bridge-cyclized $\alpha$-MSH peptide resulted in improved tumor uptake and prolonged tumor retention. Compared with ${ }^{111}$ In-DOTA-GlyGlu-CycMSH with a 12-amino acid peptide ring, ${ }^{111}$ In-DOTA-Nle-CycMSH ${ }_{\text {hex }}$ (Fig. 1) had only a 6-amino acid peptide ring. The tumor uptake $(19.39 \pm 2.72 \% \mathrm{ID} / \mathrm{g})$ of ${ }^{111}$ In-DOTA-Nle-Cy$\mathrm{cMSH}_{\text {hex }}$ was 1.86 times that of ${ }^{111}$ In-DOTA-GlyGlu-
CycMSH at $2 \mathrm{~h}$ after injection in B16/F1 melanoma-bearing C57 mice. ${ }^{111}$ In-DOTA-Nle-CycMSH ${ }_{\text {hex }}$ also exhibited more prolonged tumor retention than ${ }^{111}$ In-DOTA-GlyGluCycMSH. At $24 \mathrm{~h}$ after injection, $54.3 \%$ of the ${ }^{111} \mathrm{In}-$ DOTA-Nle-CycMSH ${ }_{\text {hex }}$ activity present at $2 \mathrm{~h}$ after injection $(10.53 \pm 1.11 \% \mathrm{ID} / \mathrm{g})$ remained in the tumors (Table 1$)$, whereas only $22.8 \%$ of the ${ }^{111}$ In-DOTA-GlyGlu-CycMSH radioactivity present at $2 \mathrm{~h}$ after injection $(2.37 \pm 0.28 \% \mathrm{ID} / \mathrm{g})$ remained in the tumors. Urinary analysis demonstrated that the ${ }^{111} \mathrm{In}-\mathrm{DOTA}-\mathrm{Nle}-\mathrm{CycMSH}_{\text {hex }}$ remained intact $2 \mathrm{~h}$ after injection (Fig. 5C). It is likely that both high in vivo stability of ${ }^{111} \mathrm{In}-\mathrm{DOTA}-\mathrm{Nle}-\mathrm{CycMSH}_{\text {hex }}$ and low $\mathrm{MC1}$ receptor dissociation rate (27) contributed to the rapid high melanoma uptake $(24.94 \pm 4.58 \% \mathrm{ID} / \mathrm{g}$ at $0.5 \mathrm{~h}$ after injection) and prolonged tumor retention $(10.53 \pm 1.11 \% \mathrm{ID} / \mathrm{g}$ at $24 \mathrm{~h}$ after injection) of ${ }^{111}$ In-DOTA-Nle-CycMSH ${ }_{\text {hex }}$ in B16/F1 melanoma-bearing $\mathrm{C} 57$ mice.

The reduction of the peptide ring size also decreased the nonspecific kidney uptake of ${ }^{111} \mathrm{In}$-DOTA-Nle-CycMSH $\mathrm{Hex}_{\text {, }}$ compared with ${ }^{111}$ In-DOTA-GlyGlu-CycMSH (21), at 2 and $4 \mathrm{~h}$ after injection. Renal uptake of ${ }^{111}$ In-DOTA-Nle$\mathrm{CycMSH}_{\text {hex }}$ was only $72.8 \%$ and $82.4 \%$ that of ${ }^{111} \mathrm{In}$ DOTA-GlyGlu-CycMSH at 2 and $4 \mathrm{~h}$ after injection, respectively. Renal uptake of ${ }^{111} \mathrm{In}$-DOTA-Nle-CycMSH hex was further reduced with L-lysine coinjection by $30 \%$ at $2 \mathrm{~h}$ after injection, demonstrating that the electrostatic interaction between ${ }^{111} \mathrm{In}-\mathrm{DOTA}-\mathrm{Nle}-\mathrm{CycMSH}_{\mathrm{hex}}$ and kidney cells played an important role in renal uptake of ${ }^{111} \mathrm{In}$ DOTA-Nle-CycMSH $\mathrm{Hex}_{\text {he }}$ The synergistic effects of an increase in tumor uptake and a decrease in renal uptake dramatically improved the tumor-to-kidney uptake ratios of ${ }^{111} \mathrm{In}-\mathrm{DOTA}-\mathrm{Nle}-\mathrm{CycMSH}_{\text {hex }}$ at all time points investigated in this study. Improved tumor uptake and decreased kidney uptake resulted in tumor-to-kidney uptake ratios of ${ }^{111} \mathrm{In}$ DOTA-Nle-CycMSH hex that were superior to those of ${ }^{111}$ In-DOTA-GlyGlu-CycMSH at 2, 4, and $24 \mathrm{~h}$ after injection. The tumor-to-kidney uptake ratios of ${ }^{111} \mathrm{In}$ DOTA-Nle-CycMSH $\mathrm{Mex}_{\text {were }} 2.55,2.79$, and 4.35 times those of ${ }^{111}$ In-DOTA-GlyGlu-CycMSH at 2, 4, and $24 \mathrm{~h}$ after injection, respectively (Fig. 4). ${ }^{111}$ In-DOTA-Nle$\mathrm{CycMSH}_{\text {hex }}$ remained intact in the urine (Fig. 5C), whereas all ${ }^{111}$ In-DOTA-GlyGlu-CycMSH transformed into 2 polar metabolites in the urine at $2 \mathrm{~h}$ after injection (21), possibly contributing to the decreased renal uptake of ${ }^{111}$ In-DOTANle-CycMSH $\mathrm{Hex}_{\text {he }}$

Recently, ${ }^{99 \mathrm{~m}} \mathrm{Tc}$-labeled lactam bridge-cyclized $\alpha-\mathrm{MSH}$ peptides $\quad\left(\left[\mathrm{Ac}-\mathrm{Nle}^{4}, \mathrm{Asp}^{5}, \mathrm{D}-\mathrm{Phe}^{7}, \mathrm{Lys}^{11}\left(\mathrm{pz}^{-}{ }^{-9 \mathrm{~m}} \mathrm{Tc}(\mathrm{CO})_{3}\right)\right] \alpha-\right.$ $\mathrm{MSH}_{4-11}$ and ${ }^{99 \mathrm{~m}} \mathrm{Tc}(\mathrm{CO})_{3}$-pz-BAla-Nle-cyclo[Asp-His-DPhe-Arg-Trp-Lys]- $\mathrm{NH}_{2}$ ) have been reported for melanoma targeting $\quad(30,31) . \quad{ }^{99 \mathrm{~m}} \mathrm{Tc}(\mathrm{CO})_{3}$-pz-BAla-Nle-cyclo[AspHis-D-Phe-Arg-Trp-Lys]- $\mathrm{NH}_{2}$ exhibited melanoma uptake $(11.31 \pm 1.81 \% \mathrm{ID} / \mathrm{g})$ superior to that of $\left[\mathrm{Ac}-\mathrm{Nle}^{4}, \mathrm{Asp}^{5}\right.$, D-Phe $\left.{ }^{7}, \mathrm{Lys}^{11}\left(\mathrm{pz}^{-}{ }^{-9} \mathrm{~m} \mathrm{Tc}(\mathrm{CO})_{3}\right)\right] \alpha-\mathrm{MSH}_{4-11} \quad(4.24 \pm 0.94$ $\% \mathrm{ID} / \mathrm{g}$ ) at $4 \mathrm{~h}$ after injection in B16/F1 melanoma-bearing C57 mice. However, ${ }^{99 \mathrm{~m}} \mathrm{Tc}(\mathrm{CO})_{3}$-pz- $\beta$ Ala-Nle-cyclo[AspHis-D-Phe-Arg-Trp-Lys]- $\mathrm{NH}_{2}$ displayed high accumulation 
and prolonged retention in both liver $(22.86 \pm 1.17 \% \mathrm{ID} / \mathrm{g})$ and kidneys $(32.12 \pm 1.57 \% \mathrm{ID} / \mathrm{g})$ at $4 \mathrm{~h}$ after injection, possibly limiting its potential application in metastatic melanoma imaging. In this study, tumor uptake of ${ }^{111} \mathrm{In}-$ DOTA-Nle-CycMSH $\mathrm{Hex}_{\text {has }} 1.5$ times that of ${ }^{99 \mathrm{~m}} \mathrm{Tc}(\mathrm{CO})_{3}{ }^{-}$ pz-BAla-Nle-cyclo[Asp-His-D-Phe-Arg-Trp-Lys]- $\mathrm{NH}_{2}$ at $4 \mathrm{~h}$ after injection, whereas liver and kidney uptake of ${ }^{111}$ In-DOTA-Nle-CycMSH ${ }_{\text {hex }}$ were only $7.5 \%$ and $31.1 \%$ that of ${ }^{99 m} \mathrm{Tc}(\mathrm{CO})_{3}$-pz-BAla-Nle-cyclo[Asp-His-D-Phe-ArgTrp-Lys]- $\mathrm{NH}_{2}$ at $4 \mathrm{~h}$ after injection. The dramatic increase in tumor uptake and decrease in liver and kidney uptake of ${ }^{111} \mathrm{In}-\mathrm{DOTA}-\mathrm{Nle}-\mathrm{CycMSH}_{\text {hex }}$ were likely due to the structural differences between ${ }^{99 \mathrm{~m}} \mathrm{Tc}(\mathrm{CO})_{3}$-pz- $\beta$ Ala-Nle-cyclo[AspHis-D-Phe-Arg-Trp-Lys]- $\mathrm{NH}_{2}$ and ${ }^{111}$ In-DOTA-Nle-Cy$\mathrm{CMSH}_{\text {hex }}$.

Currently, metal-cyclized ${ }^{111}$ In-DOTA-Re( $\left.\operatorname{Arg}{ }^{11}\right) \mathrm{CCMSH}$ showed the highest melanoma uptake among all reported ${ }^{111}$ In-labeled linear and cyclic $\alpha$-MSH peptides (17). The tumor uptake of ${ }^{111} \mathrm{In}$-DOTA-Re( $\left.\mathrm{Arg}^{11}\right) \mathrm{CCMSH}$ was $17.29 \pm$ $2.49 \% \mathrm{ID} / \mathrm{g}, 17.41 \pm 5.63 \% \mathrm{ID} / \mathrm{g}$, and $8.19 \pm 1.63 \% \mathrm{ID} / \mathrm{g}$ at 2, 4, and $24 \mathrm{~h}$ after injection, respectively (17). Remarkably, ${ }^{111}$ In-DOTA-Nle-CycMSH $\mathrm{H}_{\text {hex }}$ exhibited 1.12, 0.98 , and 1.29 times the tumor uptake of ${ }^{111}$ In-DOTA$\operatorname{Re}\left(\mathrm{Arg}^{11}\right) \mathrm{CCMSH}$ at 2,4 , and $24 \mathrm{~h}$ after injection, respectively. Meanwhile, ${ }^{111}$ In-DOTA-Nle-CycMSH ${ }_{\text {hex }}$ showed renal uptake that was slightly higher than but similar to ${ }^{111}$ In-DOTA-Re $\left(\operatorname{Arg}^{11}\right)$ CCMSH at 2 and $4 \mathrm{~h}$ after injection. ${ }^{111}$ In-DOTA-Nle-CycMSH ${ }_{\text {hex }}$ exhibited tumor-tokidney ratios comparable to ${ }^{111}$ In-DOTA-Re( $\left.\operatorname{Arg}^{11}\right) \mathrm{CCMSH}$ at 2 and $24 \mathrm{~h}$ after injection despite the fact that the tumorto-kidney uptake ratio of ${ }^{111}$ In-DOTA-Nle-CycMSH ${ }_{\text {hex }}$ was $28 \%$ less than that of ${ }^{111} \mathrm{In}$-DOTA-Re( $\left(\operatorname{Arg}^{11}\right) \mathrm{CCMSH}$ at $4 \mathrm{~h}$ after injection. It was reported that a single-dose treatment of $7.4 \mathrm{MBq}(200 \mu \mathrm{Ci})$ of ${ }^{212} \mathrm{~Pb}$-labeled DOTA$\operatorname{Re}\left(\mathrm{Arg}^{11}\right) \mathrm{CCMSH}$ resulted in $44 \%$ cures in $\mathrm{B} 16 / \mathrm{F} 1$ melanoma-bearing mice (11). Accordingly, it would be likely that treatment with ${ }^{212} \mathrm{~Pb}$-labeled DOTA-Nle-CycMSH $\mathrm{Hex}_{\text {}}$ would yield similar quantitative therapeutic effect for melanoma in the future because ${ }^{111} \mathrm{In}$-DOTA-Nle-CycMSH $\mathrm{Mex}_{\mathrm{h}}$ displayed tumor-to-kidney ratios comparable to ${ }^{111} \mathrm{In}$ DOTA-Re( $\left(\mathrm{Arg}^{11}\right) \mathrm{CCMSH}$ at 2 and $24 \mathrm{~h}$ after injection.

\section{CONCLUSION}

The ring size of the ${ }^{111}$ In-labeled lactam bridge-cyclized $\alpha$-MSH peptide exhibited a profound effect on its melanoma-targeting and pharmacokinetic properties. The reduction of the peptide ring size dramatically increased the melanoma uptake and decreased the renal uptake of ${ }^{111} \mathrm{In}$ DOTA-Nle-CycMSH $\mathrm{MS}_{\text {hex }}$, providing a new insight into the design of novel radiolabeled lactam bridge-cyclized $\alpha$-MSH peptide for melanoma imaging and treatment.

\section{ACKNOWLEDGMENTS}

We thank Benjamin M. Gershman for his technical assistance. This work was supported in part by the
Southwest Melanoma SPORE Developmental Research Program, the DOD grant W81XWH-09-1-0105, and the NIH grant NM-INBRE P20RR016480. The images in Figure 5 were generated by the Keck-UNM Small Animal Imaging Resource established with funding from the W.M. Keck Foundation and the University of New Mexico Cancer Research and Treatment Center (NIH P30 CA118100).

\section{REFERENCES}

1. Jemal A, Siegel R, Ward E, Hao Y, Xu J, Thun MJ. Cancer statistics, 2009. $C A$ Cancer J Clin. 2009;59:225-249.

2. Alonso O, Martinez M, Delgado L, et al. Staging of regional lymph nodes in melanoma patients by means of ${ }^{99 m}$ Tc-MIBI scintigraphy. J Nucl Med. 2003; 44:1561-1565.

3. Nabi HA, Zubeldia JM. Clinical application of ${ }^{18} \mathrm{~F}-\mathrm{FDG}$ in oncology. $\mathrm{J} \mathrm{Nucl}$ Med Technol. 2002;30:3-9.

4. Dimitrakopoulou-Strauss A, Strauss LG, Burger C. Quantitative PET studies in pretreated melanoma patients: a comparison of $6-\left[{ }^{18} \mathrm{~F}\right]$ fluoro-L-DOPA with ${ }^{18} \mathrm{~F}$ FDG and ${ }^{15} \mathrm{O}$-water using compartment and non-compartment analysis. $J \mathrm{Nucl}$ Med. 2001;42:248-256.

5. Miao Y, Whitener D, Feng W, Owen NK, Chen J, Quinn TP. Evaluation of the human melanoma targeting properties of radiolabeled $\alpha$-melanocyte stimulating hormone peptide analogues. Bioconjug Chem. 2003;14:1177-1184.

6. Miao Y, Owen NK, Whitener D, Gallazzi F, Hoffman TJ, Quinn TP. In vivo evaluation of ${ }^{188} \mathrm{Re}$-labeled $\alpha$-melanocyte stimulating hormone peptide analogs for melanoma therapy. Int J Cancer. 2002;101:480-487.

7. Chen J, Cheng Z, Hoffman TJ, Jurisson SS, Quinn TP. Melanoma-targeting properties of ${ }^{99 \mathrm{~m}}$ technetium-labeled cyclic $\alpha$-melanocyte-stimulating hormone peptide analogues. Cancer Res. 2000;60:5649-5658.

8. Siegrist W, Solca F, Stutz S, et al. Characterization of receptors for $\alpha$ melanocyte-stimulating hormone on human melanoma cells. Cancer Res. 1989;49:6352-6358.

9. Tatro JB, Reichlin S. Specific receptors for $\alpha$-melanocyte-stimulating hormone are widely distributed in tissues of rodents. Endocrinology. 1987;121:1900-1907.

10. Miao Y, Owen NK, Fisher DR, Hoffman TJ, Quinn TP. Therapeutic efficacy of a ${ }^{188}$ Re-labeled $\alpha$-melanocyte-stimulating hormone peptide analog in murine and human melanoma-bearing mouse models. J Nucl Med. 2005;46: $121-129$.

11. Miao Y, Hylarides M, Fisher DR, et al. Melanoma therapy via peptide-targeted $\alpha$-radiation. Clin Cancer Res. 2005;11:5616-5621.

12. Froidevaux S, Calame-Christe M, Tanner H, Eberle AN. Melanoma targeting with DOTA- $\alpha$-melanocyte-stimulating hormone analogs: structural parameters affecting tumor uptake and kidney uptake. J Nucl Med. 2005;46:887-895.

13. Froidevaux S, Calame-Christe M, Schuhmacher J, et al. A gallium-labeled DOTA- $\alpha$-melanocyte-stimulating hormone analog for PET imaging of melanoma metastases. J Nucl Med. 2004;45:116-123.

14. Froidevaux S, Calame-Christe M, Tanner H, Sumanovski L, Eberle AN. A novel DOTA- $\alpha$-melanocyte-stimulating hormone analog for metastatic melanoma diagnosis. J Nucl Med. 2002;43:1699-1706.

15. Wei L, Butcher C, Miao Y, et al. Synthesis and biologic evaluation of ${ }^{64} \mathrm{Cu}-$ labeled rhenium-cyclized $\alpha$-MSH peptide analog using a cross-bridged cyclam chelator. J Nucl Med. 2007;48:64-72.

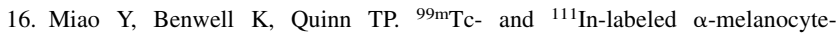
stimulating hormone peptides as imaging probes for primary and pulmonary metastatic melanoma detection. J Nucl Med. 2007;48:73-80.

17. Cheng Z, Chen J, Miao Y, Owen NK, Quinn TP, Jurisson SS. Modification of the structure of a metallopeptide: synthesis and biological evaluation of ${ }^{111}$ In-labeled DOTA-conjugated rhenium-cyclized $\alpha$-MSH analogues. J Med Chem. 2002;45: 3048-3056.

18. Cheng Z, Xiong Z, Subbarayan M, Chen X, Gambhir SS. ${ }^{64} \mathrm{Cu}-$ labeled $\alpha$-melanocyte-stimulating hormone analog for MicroPET imaging of melanocortin 1 receptor expression. Bioconjug Chem. 2007;18:765-772.

19. Wei L, Miao Y, Gallazzi F, et al. Ga-68 labeled DOTA-rhenium cyclized $\alpha$-MSH analog for imaging of malignant melanoma. Nucl Med Biol. 2007;34: 945-953.

20. Cantorias MV, Figueroa SD, Quinn TP, et al. Development of high-specificactivity ${ }^{68} \mathrm{Ga}$-labeled DOTA-rhenium-cyclized $\alpha$-MSH peptide analog to target MC1 receptors overexpressed by melanoma tumors. Nucl Med Biol. 2009;36: $505-513$. 
21. Miao Y, Gallazzi F, Guo H, Quinn TP. ${ }^{111}$ In-labeled lactam bridge-cyclized $\alpha$-melanocyte stimulating hormone peptide analogues for melanoma imaging. Bioconjug Chem. 2008;19:539-547.

22. Guo H, Shenoy N, Gershman BM, Yang J, Sklar LA, Miao Y. Metastatic melanoma imaging with an ${ }^{111}$ In-labeled lactam bridge-cyclized $\alpha$-melanocytestimulating hormone peptide. Nucl Med Biol. 2009;36:267-276.

23. Sawyer TK, Hruby VJ, Darman PS, Hadley ME. [half-Cys ${ }^{4}$,half-Cys ${ }^{10}$ ]$\alpha$-melanocyte-stimulating hormone: a cyclic $\alpha$-melanotropin exhibiting superagonist biological activity. Proc Natl Acad Sci USA. 1982;79:1751-1755.

24. Al-Obeidi F, Hadley ME, Pettitt BM, Hruby VJ. Design of a new class of superpotent cyclic $\alpha$-melanotropins based on quenched dynamic simulations. J Am Chem Soc. 1989;111:3413-3416.

25. Al-Obeidi F. de L Castrucci AM, Hadley ME, Hruby VJ. Potent and prolongedacting cyclic lactam analogs of $\alpha$-melanotropin: design based on molecular dynamics. J Med Chem. 1989;32:2555-2561.

26. Fung S, Hruby VJ. Design of cyclic and other templates for potent and selective peptide $\alpha$-MSH analogues. Curr Opin Chem Biol. 2005;9:352-358.
27. Haskell-Luevano C, Miwa H, Dickinson C, et al. Characterizations of the unusual dissociation properties of melanotropin peptides from the melanocortin receptor, hMC1R. J Med Chem. 1996;39:432-435.

28. Haskell-Luevano C, Toth K, Boteju L, et al. $\beta$-Methylation of the $\mathrm{Phe}^{7}$ and $\operatorname{Trp}^{9}$ melanotropin side chain pharmacophores affects ligand-receptor interactions and prolonged biological activity. J Med Chem. 1997;40:27402749.

29. Chen J, Cheng Z, Owen NK, et al. Evaluation of an ${ }^{111}$ In-DOTA-rhenium cyclized $\alpha$-MSH analog: a novel cyclic-peptide analog with improved tumortargeting properties. J Nucl Med. 2001;42:1847-1855.

30. Raposinho PD, Xavier C, Correia JD, Falcao S, Gomes P, Santos I. Melanoma targeting with $\alpha$-melanocyte stimulating hormone analogs labeled with fac$\left[{ }^{99 \mathrm{~m}} \mathrm{Tc}(\mathrm{CO})_{3}\right]^{+}$: effect of cyclization on tumor-seeking properties. J Biol Inorg Chem. 2008;13:449-459.

31. Raposinho PD, Correia JD, Alves S, Botelho MF, Santos AC, Santos I. A ${ }^{99 \mathrm{~m}} \mathrm{Tc}(\mathrm{CO})_{3}$-labeled pyrazolyl- $\alpha$-melanocyte-stimulating hormone analog conjugate for melanoma targeting. Nucl Med Biol. 2008;35:91-99. 